Article

\title{
Purification Effects on $\beta-\mathrm{HCH}$ Removal and Bacterial Community Differences of Vertical-Flow Constructed Wetlands with Different Vegetation Plantations
}

\author{
Qing Chen ${ }^{1}\left(\mathbb{D}\right.$, Honghu Zeng ${ }^{1,2}$, Yanpeng Liang ${ }^{2,3, *}$, Litang Qin ${ }^{1,3}$, Guangsheng Peng ${ }^{1}$, Liangliang Huang ${ }^{1,2}(\mathbb{D}$ \\ and Xiaohong Song ${ }^{1,3}$ \\ 1 College of Environmental Science and Engineering, Guilin University of Technology, Guilin 541004, China; \\ chenQ130108@163.com (Q.C.); zenghonghu@glut.edu.cn (H.Z.); qinsar@163.com (L.Q.); \\ pengguangsheng@glut.edu.cn (G.P.); llhuang@glut.edu.cn (L.H.); sxh215@163.com (X.S.) \\ 2 Collaborative Innovation Center for Water Pollution Control and Water Security in Karst Region, \\ Guilin University of Technology, Guilin 541004, China \\ 3 Guangxi Key Laboratory of Environmental Pollution Control Theory and Technology, \\ Guilin University of Technology, Guilin 541004, China \\ * Correspondence: ypliang1980@163.com; Tel.: +86-773-3693255
}

check for updates

Citation: Chen, Q.; Zeng, H.; Liang, Y.; Qin, L.; Peng, G.; Huang, L.; Song, X. Purification Effects on $\beta-\mathrm{HCH}$

Removal and Bacterial Community Differences of Vertical-Flow Constructed Wetlands with Different Vegetation Plantations. Sustainability 2021, 13, 13244. https://doi.org/ $10.3390 /$ su132313244

Academic Editor: Stefanos Giannakis

Received: 6 November 2021

Accepted: 24 November 2021

Published: 30 November 2021

Publisher's Note: MDPI stays neutral with regard to jurisdictional claims in published maps and institutional affiliations.

Copyright: (c) 2021 by the authors. Licensee MDPI, Basel, Switzerland. This article is an open access article distributed under the terms and conditions of the Creative Commons Attribution (CC BY) license (https:/ / creativecommons.org/licenses/by/ $4.0 /)$.

\begin{abstract}
This study aimed to investigate the removal of $\beta$-hexachlorocyclohexane $(\beta-\mathrm{HCH})$ at realistic concentration levels $(10 \mu \mathrm{g} / \mathrm{L}$ ) in different plant species in constructed wetlands (Acorus calamus, Canna indica, Thalia dealbata, and Pontederia cordata) and the structure of the rhizosphere microbial community response of each group during summer and winter. Results showed that all groups of constructed wetlands had very good decontamination efficiency against $\beta-\mathrm{HCH}$ in water (90.86-98.17\%). The species that most efficiently purified $\beta-\mathrm{HCH}$ in water was A. calamus in summer $(98.17 \%)$ and C. indica in winter $(96.64 \%)$. Substrate sorption was found to be the major pathway for $\beta-\mathrm{HCH}$ removal from water in the constructed wetlands. The ability of the wetland plants to absorb and purify $\beta-\mathrm{HCH}$ was limited, and $\mathrm{C}$. indica had the strongest absorptive capacity among the four plant species. The mean $\beta-\mathrm{HCH}$ removal from the matrix of the planted plants increased by $5.8 \%$ compared with that of the control treatment (unplanted plants). The average $\beta-\mathrm{HCH}$ content in the plant rhizosphere substrate was $4.15 \mu \mathrm{g} / \mathrm{kg}$ lower than that in the non-rhizosphere substrate. High-throughput sequencing analysis revealed significant differences $(P<0.05)$ in the Chao1 and ACE indices of microbes in the substrate of four wetlands during summer and winter. At the genus level, the constructed wetlands with vegetation plantations showed higher microbial abundance than the constructed wetlands without vegetation plantations. In winter, the bacterial community structure of each constructed wetland was quite different, but no dominant flora in the bacterial community structure obviously changed. In summer, the bacterial community structure at the same stage was relatively small. The abundance of Actinobacteria and Sphingomonas remarkably increased over time in summer.
\end{abstract}

Keywords: $\beta-\mathrm{HCH}$; purification effects; vertical-flow constructed wetlands; bacterial community

\section{Introduction}

Hexachlorocyclohexanes (HCHs) are persistent organic pollutants of global concern and common organochlorine pesticides (OCPs) [1]. HCHs are widely used as pesticides in agricultural production because of their low cost and high efficiency [2]. Although HCHs have been completely banned since the 1970s by various countries and their toxicity had been remedied through various means, high amounts of $\mathrm{HCH}$ residues are still detected in the environment because of their stable properties and the long-range migration characteristics of some of their isomers, posing a serious risk to the global terrestrial and marine ecology [3-5]. HCHs have eight isomers, with $\alpha, \beta, \gamma$, and $\delta$ as the main forms [6]. 
Among all isomers, the $\beta$-isomer has the lowest volatility, the strongest stability, the longest half-life, and is the most difficult to biodegrade $[7,8] . \beta-\mathrm{HCH}$ is also a halogenated organic substance with extremely low water solubility and biological toxicity, as well as an endocrine disruptor. It can easily accumulate in the adipose tissues and the central nervous system of invertebrates and birds owing to its lipid solubility; thus, it can damage the mammalian reproductive and nervous systems and cause cellular inflammation or DNA damage. Moreover, it is a high-risk carcinogenic teratogenic contaminant [9-11]. The $\mathrm{HCH}$ isomers $\alpha, \beta$, and $\gamma$ were listed as persistent organic substances in the 2011 Stockholm Convention because of their harmful effects [12].

Constructed wetlands (CWs), which are artificially simulated to follow the operation patterns of natural wetlands, are a comprehensive ecological treatment technology for decontaminating sewage [13]. Owing to their cost, operation convenience, low management expense, high efficiency, and general applicability, CWs are widely used in the treatment of municipal domestic wastewater worldwide as they can effectively remove excess ammonia in water bodies and most organic matter, and they also have a certain aesthetic value [14-17]. The important compositions of CWs are plants, substrates, and microorganisms [18]. The basic principle of CWs is to purify all types of pollution in water bodies through a series of physical, chemical, and biological interactions via adsorption from soil matrix, plant uptake, and microbial degradation [19]. Microorganisms in wetland systems play an extremely important role in degrading water pollutants [20]. This role is related to the plant rhizosphere environment, wherein a well-developed root system is conducive to microbial attachment, and oxygen secretion by the rhizosphere can also provide a more suitable environment for aerobic microorganisms to perform physiological activities, making them metabolically more active, and some pollutants also need to undergo aerobic-anaerobic processes before they can be completely removed [21-23]. Currently, several technologies have been developed for water remediation: for example, natural materials are widely recognized by the scientific community as high potential substrates for many purposes. In particular, functionalization processes of natural substrates have improved the affinity of the developed bio-sorbents towards several classes of pollutants and significantly improved their removal effect on said pollutants, such as heavy metals and dyes [24], organic compounds [25,26], endocrine disrupting compounds [27], and hydrocarbons [28].

Many studies have been conducted on OCPs from CWs. OCPs accumulate in abundant amounts in the matrixes and surface sediments of wetlands, and phytosorption has been shown to be a useful removal method [29]. However, studies on the CW removal of pesticides largely focused on the role of the matrix and plants in wetlands. In this study, a series of experiments were conducted by constructing different plant groups in winter and summer to explore changes in the community structural characteristics of rhizosphere microorganisms in the process of removing $\beta-\mathrm{HCH}$ from $\mathrm{CW}$ systems. This study provides a clear understanding of the mechanism of $\beta-\mathrm{HCH}$ removal by $\mathrm{CW}$ plant-coupled microorganisms.

\section{Materials and Methods}

\subsection{Experimental Setup and Operating Conditions}

The simulated CW model (Figure 1) was an aluminum vessel with a dimension of $1.0 \mathrm{~m} \times 0.5 \mathrm{~m} \times 0.6 \mathrm{~m}$. It was constructed within the campus of Guangxi Guilin University of Technology, China. Cobblestones with a particle size of about $2.0-3.0 \mathrm{~cm}$ were uniformly laid on the bottom of the vessel at a height of $10 \mathrm{~cm}$. Cobblestones in the soil collected from the surrounding croplands at the Huixian Wetland, in the Guilin region of Guangxi, China, were further added to a depth of $20 \mathrm{~cm}$. A water outlet with a diameter of $20 \mathrm{~cm}$ was also set at $1.0 \mathrm{~cm}$ from the bottom of the container, and a tap made of polyvinyl chloride was used to collect water samples. 


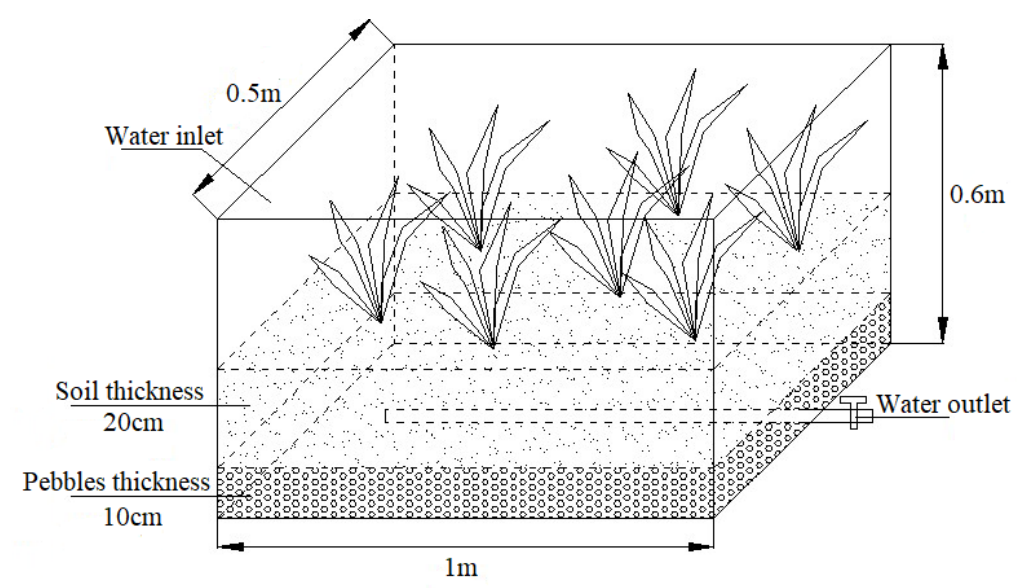

Figure 1. Simulation device of the vertical-flow constructed wetland.

The plants selected in this study were locally dominant CW species, namely, Acorus calamus (group C), Canna indica (group M), Thalia dealbata (group Z), and Pontederia cordata (group S). Each CW unit was planted at a density of 20 plants, with two groups per plant setup. Other groups based on the propylene-based theorem were administered as microbial growth inhibitors and denoted as groups CY, MY, ZY, and SY. Two more blank control groups, denoted as $\mathrm{K}$ and $\mathrm{KY}$ groups, were established for a total of 10 groups of models. The influence of seasonal variations on each stage of $\mathrm{CW}$ operation was explored in winter and summer. This experiment was operated in an intermittent water-in and water-out mode with a single cycle of 15 days and four cycles of continuous water intake, for a total of 60 days. Each water intake of the simulated domestic wastewater was $30 \mathrm{~L}$. The experimental water was artificial water, which was constructed from the configurations of potassium dihydrogen sulfate, starch, ammonium chloride, and potassium nitrate. The parameters of the experimental water were as follows: $\beta-\mathrm{HCH}$ concentration was $0.01 \mathrm{mg} / \mathrm{L}$; $\mathrm{pH}$ was 6.90-7.30; COD was $102-105 \mathrm{mg} / \mathrm{L}$; and the mass concentrations of $\mathrm{DO}, \mathrm{NH}_{4}^{+}-\mathrm{N}, \mathrm{TN}$, and TP were 3.6-4.8, 20-25, 35-40, and 2.0-3.5 mg/L, respectively.

\subsection{Sample Collection}

During the experimental period, water samples were collected at regular intervals of $1,5,9,15,22,30,37,45,52$, and 60 days. The matrix acquisition times were consistent with the water sample collection. The non-rhizosphere matrix was taken $0.05 \mathrm{~m}$ below the surface soil of the wetlands, whereas the rhizosphere was taken from plant rhizosphere bags on days 1, 15, 30, and 60 and used as the soil bacterial samples for sequencing.

\subsection{Instrumentation and Chemicals}

The instruments used in the analytical determination in this experiment were as follows: GC/ECD (PerkinElmer, Waltham, MA, USA); column (Agilent, Santa Clara, CA, USA); solid-phase extraction device (Limited Japan); ultrasonic cleaner (Kunshan Ultrasonic Instrument); 24 position nitrogen blow instrument (Agilent, Santa Clara, CA, USA); freeze dryer (Great Wall Scientific Trade, China); benchtop centrifuge (Shanghai Anting Technology); ultrapure water meter (Millipore, Burlington, MA, USA); and portable $\mathrm{pH}$ meter (Shanghai lichen Instrument Technology).

$\beta-\mathrm{HCH}$ standards (n-hexane solution; purity $>99.0 \%$ ) were acquired at the Environmental Quality Surveillance and Inspection Testing Center, Ministry of Agriculture, China. $\mathrm{N}$-hexane, acetone, and methanol were purchased from Tedia Company, Fairfield, OH, USA. Ethyl acetate and dichloromethane were obtained from Shanghai Aladdin, both of which were chromatographically pure. 


\subsection{Sample Analysis}

The content of $\beta-\mathrm{HCH}$ in each sample was subjected to solid-phase extraction and then analyzed via gas chromatography with an electron capture detector (ECD) and an autosampler with split injection (PerkinElmer, Waltham, MA, USA), using a 10:1 split ratio, injection volume of $0.8 \mu \mathrm{L}$, and injection port temperature of $250{ }^{\circ} \mathrm{C}$. The detector temperature was $320^{\circ} \mathrm{C}$. High-purity nitrogen was used as the carrier gas. The sample loading time for each sample was $26 \mathrm{~min}$, and the time to peak for $\beta-\mathrm{HCH}$ ranged from $18 \mathrm{~min}$ to $19 \mathrm{~min}$.

The V4 + V5 region of 16S rDNA was amplified via polymerase chain reaction (PCR) by using diluted genomic DNA as template and specific primers (515F and 806R) with barcode, Phusion high-fidelity PCR master mix (Elabscience, Wuhan, China) with GC buffer (New England Biolabs), and high-efficiency high-fidelity enzyme. The PCR reaction system $(30 \mu \mathrm{L})$ included $15 \mu \mathrm{L}$ Phusion Master Mix $(2 \times)$ (Elabscience, Wuhan, China), $3 \mu \mathrm{L}$ primer $(2 \mu \mathrm{mol} / \mathrm{L}), 10 \mu \mathrm{L} \mathrm{g}$ DNA $(1 \mathrm{ng} / \mu \mathrm{L})$, and $2.0 \mu \mathrm{L} \mathrm{H}_{2} \mathrm{O}$. The reaction procedures for PCR amplification involved pre-denaturation at $98^{\circ} \mathrm{C}$ for $1 \mathrm{~min}, 30$ cycles (denaturation at $98^{\circ} \mathrm{C}$ for $10 \mathrm{~s}$, annealing at $50^{\circ} \mathrm{C}$ for $30 \mathrm{~s}$, and extension at $72{ }^{\circ} \mathrm{C}$ for $30 \mathrm{~s}$ ), and extension at $72{ }^{\circ} \mathrm{C}$ for $5 \mathrm{~min}$. Amplification products were detected via electrophoresis by using $2 \%$ agarose gel. The samples were subjected to DNA purification and recovery by using MagicPure size selection DNA bead kits (Nanjing Jiancheng Biological Engineering Research Institute Co., Ltd. Nanjing, China). High-throughput sequencing was performed on Illumina MiSeq platform (Illumina, San Diego, CA, USA).

\subsection{Data Analysis}

Statistical analyses were performed using Excel (v 2019, Microsoft Corporation: Redmond, WA, USA) and SPSS (v21.0., IBM: Armonk, NY, USA). Graphs were drawn using Origin (v2017, OrignLab: Northampton, MA, USA). The statistical significance of $\beta-\mathrm{HCH}$ concentrations was analyzed. One-way ANOVA at $95 \%$ confidence level $(P<0.05)$ was used to evaluate significant differences in the concentrations of $\beta-\mathrm{HCH}$ between the two seasons and each group. Microbial data were analyzed using R software (v2.25.3, Parametric Technology Corporation: Boston, MA, USA), UPARSE v7.0.1001 (http:/ / www.drive5.com/uparse/) (accessed on 13 September 2021), and MUSCLE v3.8.31 (http:/ / www.drive5.com/muscle/) (accessed on 13 September 2021).

\section{Results and Discussion}

\section{1. $\beta$-HCH Removal}

\subsubsection{Removal of $\beta-\mathrm{HCH}$ in Water}

The $\beta-\mathrm{HCH}$ in the $\mathrm{CW}$ water bodies was rapidly removed in the first 5 days after the start of the experiment (Figure 2). This result can be attributed to the sorption of the substrate. $\beta-\mathrm{HCH}$ is a hydrophobic pesticide. Studies have shown that the particles of some pesticides, after entering the water body, can combine with fine particles of organic matter in the water to produce a physical sedimentation effect. The pesticides in water are then quickly removed through the sorption of the substrate. Nonpolar organic pollutants are first sorbed onto the organic matter-rich substrate through the hydrophobic process. This process is especially true in the case of treating wastewater contaminated with organic compounds that are difficult to biodegrade. Various materials, such as activated carbon added to the $\mathrm{CW}$ substrate and biochar infiltrated with $\mathrm{Fe}$, have a great sorption capacity and removal of hydrophobic contaminants [29-32]. An undulatory trend of the remaining concentration of $\beta-\mathrm{HCH}$ was observed due to the new $\beta-\mathrm{HCH}$ was added in the subsequent periods. The removal rate of $\beta-\mathrm{HCH}$ in the water bodies in winter and summer was not remarkably different. The removal rate of group $\mathrm{K}$ was lower than that of the reactor with plants. This result proved that planting of plants can reduce the effluent concentration of $\beta-\mathrm{HCH}$. However, the final removal rate of group $\mathrm{K}$ was not substantially different from that of the CWs of planted plants. The removal rates of groups $\mathrm{K}, \mathrm{C}, \mathrm{M}, \mathrm{Z}$, and $\mathrm{S}$ were $90.86-96.64 \%$ in winter and $92.98-98.17 \%$ in summer. Compared with that of group $\mathrm{K}$, 
the decontamination rate of $\beta-\mathrm{HCH}$ from the CWs' water bodies with plants increased by $3.6-5.78 \%$ in winter and $1.49-5.19 \%$ in summer. In both seasons, group $Z$ had the lowest treatment effect. Group $C$ had the best treatment effect in summer group $M$ in winter. The data on the final $\beta-\mathrm{HCH}$ removal rate of each group of $\mathrm{CW}$ water body are presented in Table S1. Results showed that the administration of microbial inhibitors only slightly reduced the purification capacity of the water bodies for $\beta-\mathrm{HCH}$.
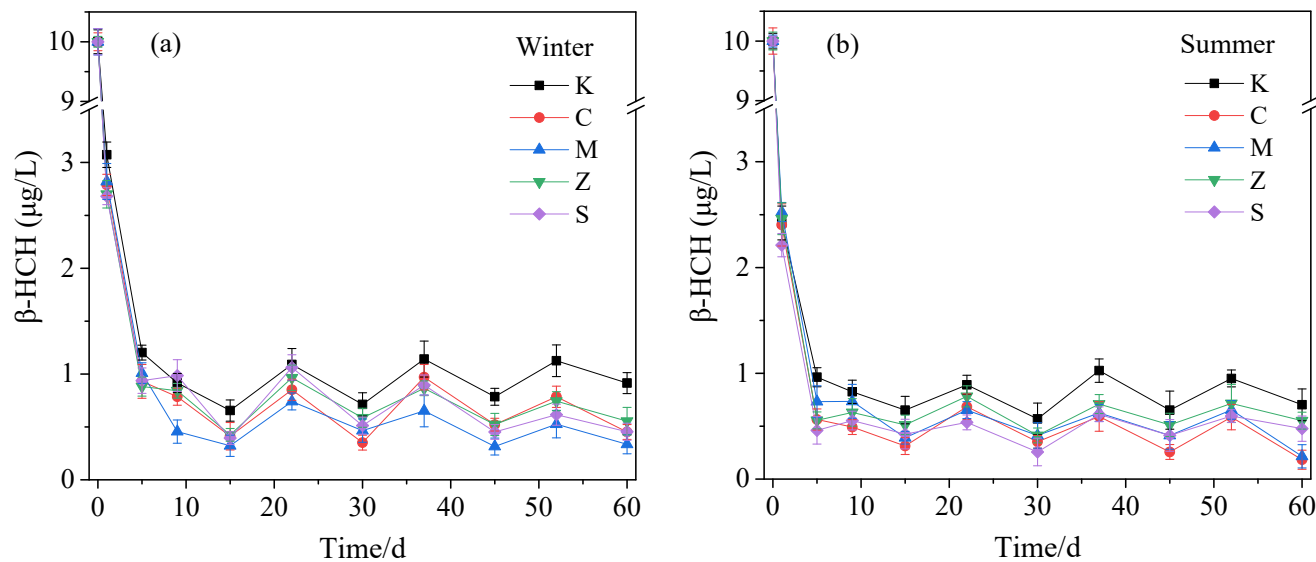

Figure 2. Concentration of $\beta-\mathrm{HCH}$ in the water of different phytoconstructed wetlands in winter (a) and summer (b) with time trends. K refers to no plant in the constructed wetland, $\mathrm{C}$ refers to planted with Acorus calamus, M refers to planted with Canna indica, Z refers to planted with Thalia dealbata, and $\mathrm{S}$ refers to planted with Pontederia cordata.

\subsubsection{Plant Uptake}

Starting on the 7 th day, $\beta-\mathrm{HCH}$ was detected from various plants at levels ranging from $0.25 \mu \mathrm{g} / \mathrm{kg}$ to $0.71 \mu \mathrm{g} / \mathrm{kg}$. After the CWs were operated for 60 days, the average contents of $\beta-\mathrm{HCH}$ in the plants of groups $\mathrm{C}, \mathrm{M}, \mathrm{Z}$, and $\mathrm{S}$ were $2.96,3.92,1.98$, and $3.38 \mu \mathrm{g} / \mathrm{kg}$, respectively, in winter (Figure $3 \mathrm{a}$ ) and 3.96, 4.91, 2.55, and $3.52 \mu \mathrm{g} / \mathrm{kg}$, respectively, in summer (Figure $3 b$ ). Compared with that in winter, the uptake of $\beta-\mathrm{HCH}$ by the plants increased by $0.57-0.99 \mu \mathrm{g} / \mathrm{kg}$ in summer. In both seasons, $C$. indica had the best uptake capacity for $\beta-\mathrm{HCH}$. Its uptake capacity for $\beta-\mathrm{HCH}$ was higher by $23.98-92.54 \%$ than the other plants in this study.
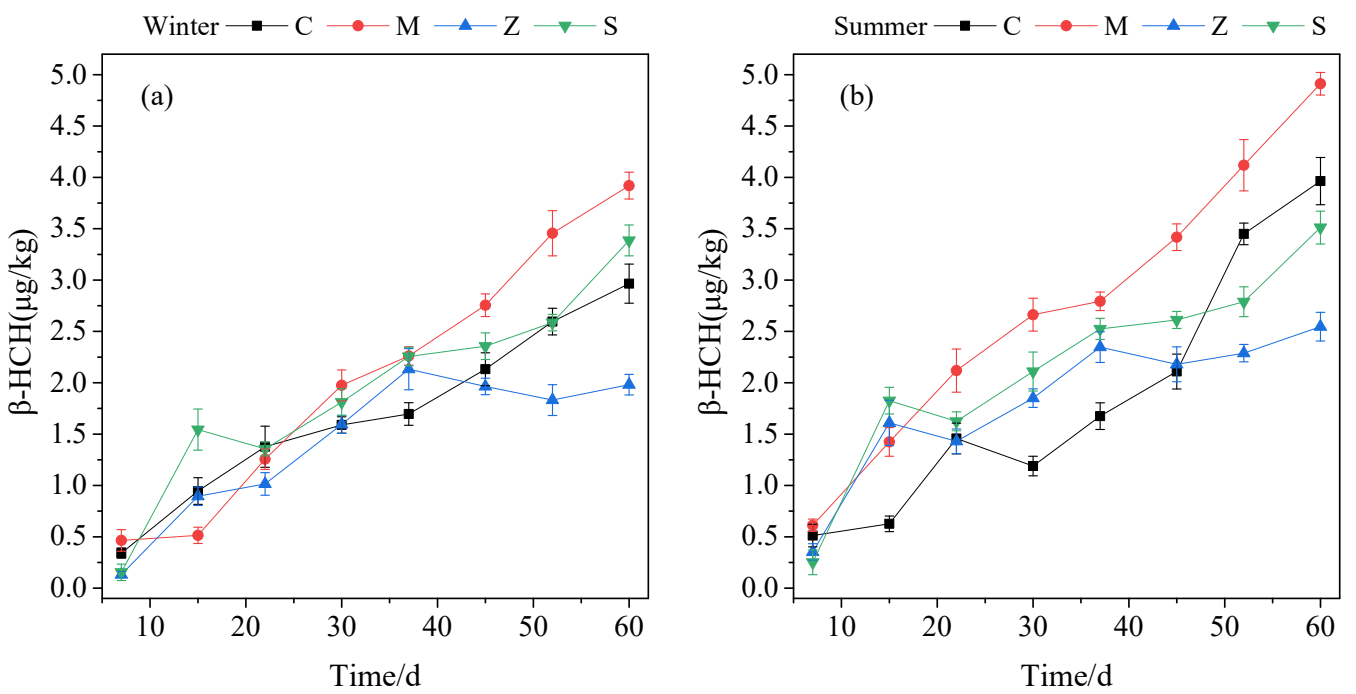

Figure 3. Concentrations of $\beta-\mathrm{HCH}$ that accumulated in the different plant species with time trends in winter (a) and summer (b). 
Bioaccumulation factor (BCF) can be utilized to characterize the ability of plants to accumulate organic pollutants; the larger the BCF value, the stronger is the ability of plants to absorb pesticides [33]. The BCF value of groups C, M, Z, and S was $0.2955,0.3921,0.181$, and 0.3386 , respectively, in winter and $0.3964,0.4912,0.2546$, and 0.3511 , respectively, in summer. This result showed that $C$. indica had the strongest $\beta-\mathrm{HCH}$ uptake capacity in this study. Well-developed root systems are more prone to microbial attachment; thus, they can further improve the purification of pollutants [20]. In Phragmites and Typha, HCHs are mainly distributed in the roots and leaves after they enter plant tissues [29]. Among the plant species in this study, $C$. indica had a more developed root system, taller stems, and larger leaves, properties which were conducive to the enrichment of $\beta-\mathrm{HCH}$. The addition of microbial inhibitors had no remarkable effect on the process of $\beta-\mathrm{HCH}$ uptake by the plants and only marginally reduced the $\beta-\mathrm{HCH}$ sorption by the plants (Table S2). Thus, further studies on the relationship between pesticide uptake by plants and microorganisms are warranted.

\subsubsection{Substrate Sorption}

The content of $\beta-\mathrm{HCH}$ in both the rhizosphere and nonrhizosphere substrates steeply increased and peaked in the first 5 days in both seasons (Figure $4 a-d$ ). This result demonstrated that the substrate had a considerable sorption effect on $\beta-\mathrm{HCH}$. Some studies found that the pesticide adsorption by substrates in CWs depends on the physicochemical properties of the pesticide, and it is more likely to be adsorbed by the substrates when the Log Kow value of the pesticide is $>3$, but the pesticide cannot easily cross the biofilm into the plant stem and other tissues [34,35]. In this study, the Log Kow value of $\beta-\mathrm{HCH}$ was 3.89, indicating that it was easily sorbed by the substrate. The first cycle was taken as an example to evaluate the removal effect of $\beta-\mathrm{HCH}$ in the CWs' substrate. The removal rate of $\beta-\mathrm{HCH}$ in the rhizosphere substrate of groups $C, M, Z$, and $S$ was $36.25 \%, 46.41 \%, 45.75 \%$, and $2.00 \%$, respectively, in winter and $22.26 \%, 52.16 \%, 32.17 \%$, and $13.21 \%$, respectively, in summer. The removal rate of $\beta-\mathrm{HCH}$ by groups $\mathrm{K}, \mathrm{C}, \mathrm{M}, \mathrm{Z}$, and $\mathrm{S}$ in the non-rhizosphere substrate was $12.66 \%, 40.57 \%, 34.02 \%, 31.32 \%$, and $41.52 \%$, respectively, in winter and $10.79 \%, 34.11 \%, 10.99 \%, 23.75 \%$, and $14.01 \%$, respectively, in summer. In both seasons, the content of $\beta-\mathrm{HCH}$ was higher in the non-rhizosphere substrate than that in the rhizosphere substrate. Meanwhile, group $\mathrm{K}$ had the highest amount of residue. Therefore, the planting of plants had a substantial effect on the purification of $\beta-\mathrm{HCH}$ in the $\mathrm{CWs}$. According to previous studies, various pollutants, such as pesticides, are removed primarily via substrate absorption, while a small fraction are removed by plant uptake, and a further proportion are degraded by microorganisms present in wetlands. However, the degradation capacity of microorganisms is limited. Several factors, such as the organic matter of the substrate, temperature, $\mathrm{pH}$, and plant rhizosphere oxygen and secretions, can affect the degradation of pollutants by microorganisms [30,36,37].

The addition of microbial inhibitors considerably affected the final content of $\beta-\mathrm{HCH}$ in the CW substrate (Tables S3 and S4). The final content of $\beta-\mathrm{HCH}$ in the non-rhizosphere and rhizosphere substrates after the addition of microbial inhibitors was $3.74 \%$ and $8.78 \%$, respectively, higher in winter and $12.35 \%$ and $12.15 \%$, respectively, higher in summer than that in the groups without microbial inhibitors. This difference may be attributed to the fact that the microbes were more active during summer; thus, the plants' response to the microbial inhibitors was more pronounced. In a short period of time, the rates of hydrolysis, evaporation, and photolysis of $\beta-\mathrm{HCH}$ in natural environments are minimal [8]. Therefore, in this study, the plant uptake, substrate sorption, and microbial degradation were the main factors that affected the removal of $\beta-\mathrm{HCH}$ in $\mathrm{CWs}$. The administration of microbial inhibitors in this study had little constitutive effect on water purification and plant uptake, indicating that the microbial inhibitors influenced the degradation of $\beta-\mathrm{HCH}$ by the microorganisms present in the CWs' substrates. 

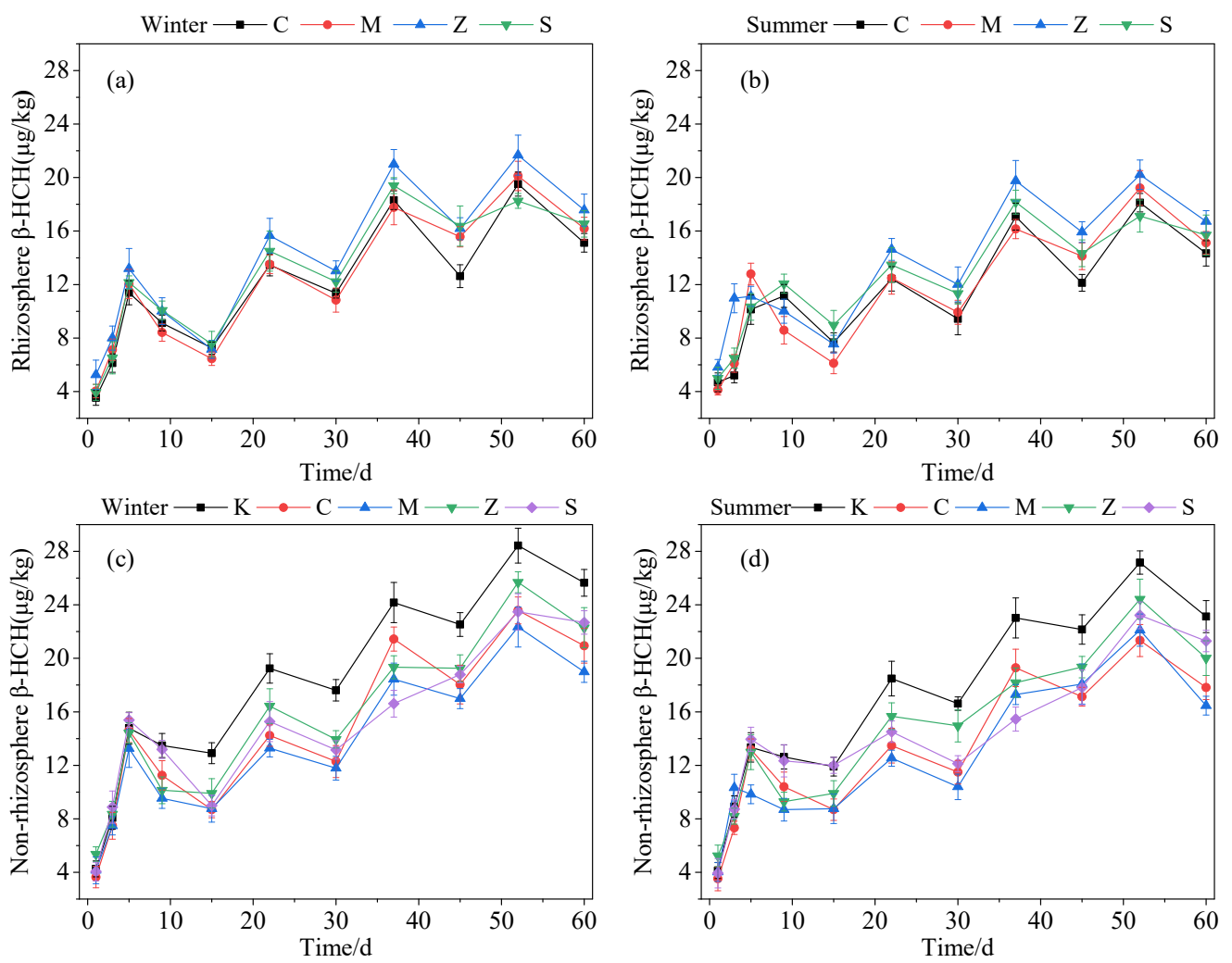

Figure 4. Amounts of $\beta-\mathrm{HCH}$ that accumulated in the rhizosphere substrate in winter (a) and summer (b) and in the non-rhizosphere substrate in winter (c) and summer (d) with time trends.

\subsection{Bacterial Community Structure}

The purification of pollutants in CWs is inseparable from the contribution of microorganisms [21]. Therefore, changes in the community response of the substrates' microorganisms during $\beta-\mathrm{HCH}$ purification in the $\mathrm{CWs}$ were measured to explore their important role in $\beta-\mathrm{HCH}$ degradation.

\subsubsection{Alterations in Abundance and Diversity of Bacterial Community Caused by $\beta-\mathrm{HCH}$}

The high-throughput sequencing data of 80 samples obtained a total of 77 phyla, 96 classes, 177 orders, 311 families, 704 genera, and 482 species of bacteria. The bacterial dilution curve of the 80 samples during the operation of the CWs in winter and summer is plotted in Figure S1. The curve in both seasons gradually approached the saturation plateau. Thus, the amount of sequencing data was reasonable.

Homogenizing the bacterial diversity data across all samples resulted in an average diversity index of the bacterial community in each CW at different stages (Table 1). As the test progressed in winter, no obvious difference in bacterial community diversity index was observed. However, the Shannon index and the Chao1 index of the CWs at different stages were notably higher in each group in summer compared with before $\beta-\mathrm{HCH}$ was administered. This result indicated that in summer, the bacteria in the CWs responded more strongly to $\beta-\mathrm{HCH}$, and they had a regular growth. In addition, all bacterial diversity indices were greater in the CWs in summer than that in winter (Table S5). No significant difference in the OTU and Shannon indices were detected in both seasons $(P>0.05)$, but their Chao1 and Ace indices were significantly different $(P<0.05)$. 
Table 1. Bacterial diversity index analysis results of constructed wetlands in winter and summer.

\begin{tabular}{cccccc}
\hline Sample Name & OTU & Shannon & Chao1 & Ace & Goods Coverage \\
\hline Winter 1 & 3143 & 9.151 & 3534 & 3577 & 0.986 \\
Winter 15 & 3114 & 9.319 & 3830 & 3632 & 0.985 \\
Winter 35 & 3088 & 8.913 & 3447 & 3500 & 0.987 \\
Winter 60 & 3173 & 9.240 & 3545 & 3584 & 0.987 \\
Summer 1 & 3039 & 8.802 & 3516 & 3636 & 0.981 \\
Summer 15 & 3255 & 9.297 & 3899 & 4006 & 0.978 \\
Summer 35 & 3453 & 9.721 & 4242 & 4332 & 0.975 \\
Summer 60 & 3343 & 9.547 & 4429 & 4347 & 0.975 \\
\hline
\end{tabular}

The number represents the running days of the model at the sampling time, where 1 meant that $\beta-\mathrm{HCH}$ had not been added yet.

The CWs' bacterial diversity index for each group is given in Table 2. Significant differences $(P<0.05$ were observed in the community structure and number of bacteria in the CWs of different plant species. The species and number of bacteria in group $S$ were fewer than those in group K, probably because of the greater inhibition of $\beta-\mathrm{HCH}$ in the rhizosphere bacteria of Pontederia cordata within a short period of time. The use of lindane $(\gamma-$ $\mathrm{HCH}$ ) inhibits the growth of barley plants to a certain extent, and it also affects the changes in the structure of soil bacteria, especially rhizosphere bacteria [38]. Al-Ani et al. [39] reported that the use of $\alpha$-cypermethrin and malathion in soil substantially reduced the number of fungi and actinomycetes and inhibits soil microbial activity. However, the influence of the toxicity of pesticides on soil microorganisms does not last forever. Soil microorganisms will make some corresponding changes, such as mutations to produce resistance to pesticides or expression of specific genes and hydrolytic enzymes to degrade pesticides and develop adaptability $[40,41]$.

Table 2. Analysis results of plant species and bacterial diversity index of constructed wetland.

\begin{tabular}{cccccc}
\hline Sample Name & OTU & Shannon & Chao1 & Ace & Goods Coverage \\
\hline K & 3145 & 9.199 & 3984 & 3793 & 0.982 \\
C & 3293 & 9.514 & 4480 & 4048 & 0.980 \\
M & 3301 & 9.790 & 4023 & 3933 & 0.981 \\
Z & 3284 & 9.356 & 4025 & 3929 & 0.981 \\
S & 3097 & 9.143 & 3954 & 3781 & 0.981 \\
\hline
\end{tabular}

Principal component analysis (PCA) of operational taxonomic units was performed on each sample to examine further the differences in bacterial communities among the $\mathrm{CW}$ groups (Figure 5). The components of each sample showed dispersion in winter, indicating that the bacterial community composition of each group was quite different in each season. Principal coordinate 1 (PC1) and principal coordinate 2 (PC2) in winter and summer (which explained $15.98 \%$ and $14.67 \%$, respectively) showed that $\beta-\mathrm{HCH}$ only slightly changed the bacterial community structure. The CWs' samples in summer clustered in the PCA plot, and the samples on the 60th day were exclusively located to the right of PC1, which was primarily responsible for the differences. The distance between samples in groups $\mathrm{C}$ and $\mathrm{M}$ became larger over time. Analyses of the efficacy of various plant CWs in $\beta-\mathrm{HCH}$ removal revealed that the bacterial communities of $A$. calamus and $C$. indica diverged in a direction favoring $\beta-\mathrm{HCH}$ degradation, leading to large differences in their communities. In addition, the samples of the dosed microbial inhibitor group were less distant from the samples of the non-dosed microbial inhibitor group, indicating that the microbial inhibitors had little effect on bacterial community diversity. Therefore, the effects of microbial inhibitors were ignored in subsequent analyses. 

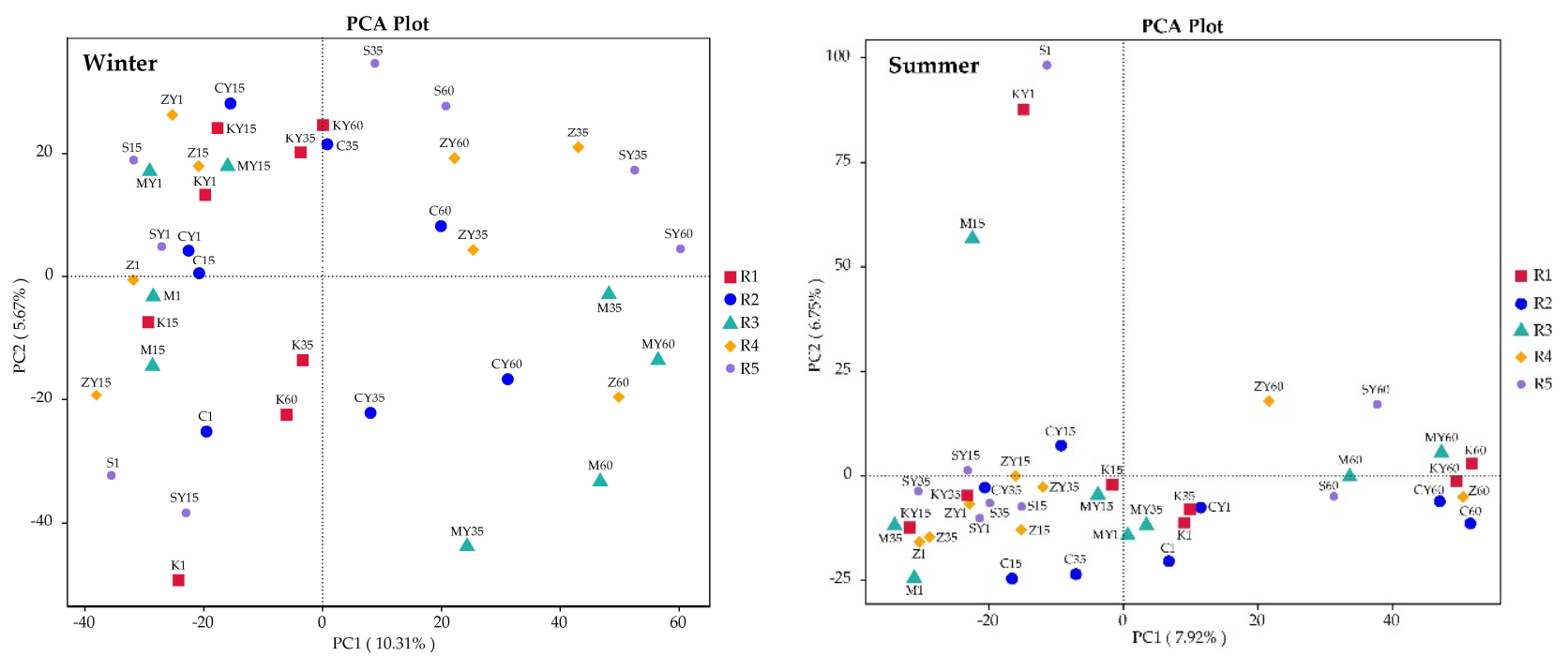

Figure 5. Principal component analysis of bacteria in the CWs of different plants in winter (left) and summer (right). The values in parentheses of the $\mathrm{x}$ - and $\mathrm{y}$-axes show the percentages of the community variation explained. R1 refers to no plant, $\mathbf{R} 2$ refers to Acorus calamus, $\mathbf{R} 3$ refers to Canna indica, $\mathbf{R} 4$ refers to Thalia dealbata, and $\mathbf{R} \mathbf{5}$ refers to Pontederia cordata.

\subsubsection{Bacterial Community at the Phylum Level in Both Seasons and in Different Plants}

The top 10 bacterial phyla with relative abundance in the CWs of each group in both seasons are shown in Figure $6 \mathrm{a}, \mathrm{b}$. The bacterial phyla with an average relative abundance of over $4 \%$ in each group in both seasons were the same and mainly contained Proteobacteria, Chloroflexi, Acidobacteria, Rokubacteria, Actinobacteria, and Firmicutes, and these strains occupied a dominant position (accounted for over $80 \%$ of the total microorganisms). Proteobacteria was the most dominant phylum occupying the absolute dominance in the five groups of CWs. This result was similar to that of previous studies [42,43]. As shown in Figure $6 c$, the difference in season had a certain effect on bacterial diversity. Hence, the bacterial community occupancy changed, but no significant difference was observed in bacterial community diversity at the phylum level $(P>0.05)$.
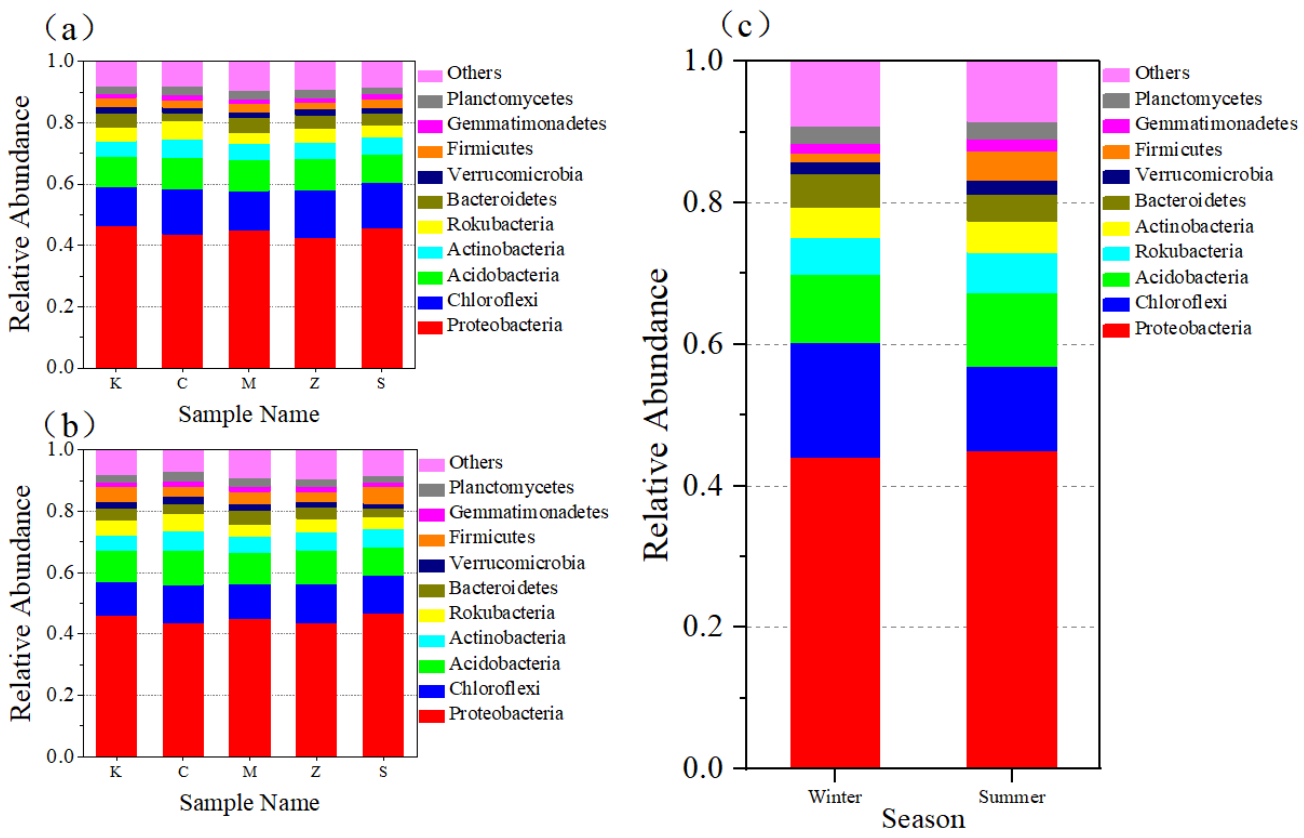

Figure 6. Relative abundance of bacterial phyla in different plant groups in winter (a). Relative abundance of bacterial phyla in different plant groups in summer (b). Difference in relative abundance of bacterial phyla between winter and summer (c). 
As the experiment progressed, the proportion of Firmicutes and Actinobacteria gradually increased in each $\mathrm{CW}$ in summer, but the changes in other phyla were not significant (Table S6). A study found that Firmicutes and Actinobacteria were abundant in two different soils that had been contaminated with pesticides for a long time [44]. Previous studies showed that Actinomycetes, especially Streptomyces, has a great potential to degrade various organochlorine pesticides $[45,46]$. With regard to HCHs, Streptomyces sp. M7 isolated by a $\mathrm{CW}$ system has a high degradation efficiency for $\alpha / \beta-\mathrm{HCH}$, and the degradation rate for $\alpha$ and $\beta$ isomers within 7 days is $80 \%$ and $78 \%$, respectively [47].

\subsubsection{Bacterial Community at the Genus Level in Both Seasons and in Different Plants}

Significant differences at the genus level were observed $(P<0.05)$ between winter and summer. Stenotrophomonas, Malaysia, and Lysobacter appeared only in winter, whereas Sphingomonas and Streptomyces appeared only in summer, and their abundance continued to increase. Differences in the bacterial genera of the CWs among the groups in both seasons are shown in Figure $7 \mathrm{a}, \mathrm{b}$. The differences at the genus level between the CWs of each group in winter were relatively negligible, whereas the differences at the genus level between the CWs of each group in summer were significant. Moreover, the bacterial communities in winter and summer were significantly different at the genus level $(P<0.05)$. The data of bacterial community distribution at the genus level of all samples were treated uniformly to obtain the top 10 bacterial genera in terms of relative abundance at the bacterial genus level in both seasons to explore further the dynamic changes in bacterial community structure (Figure 7c). The bacterial community structure in winter and summer was significantly different at the genus level. Studies have shown that seasonal variations and cultivation of different plants have a great impact on changes in the bacterial community structure of CWs and are particularly evident at the genus level [48,49], consistent with the results of the present study.
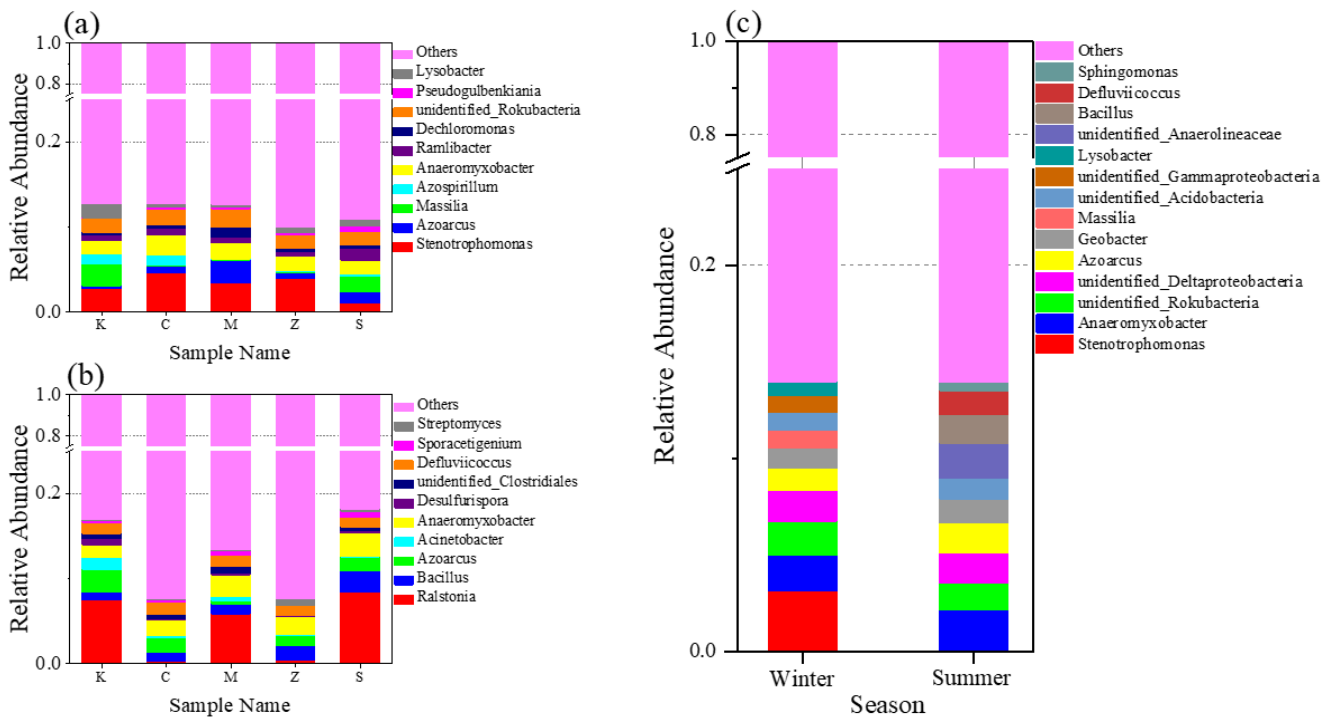

Figure 7. Relative abundance of bacterial genera in different plant groups in winter (a). Relative abundance of bacterial genera in different plant groups in summer $(\mathbf{b})$. Differences in the relative abundance of bacterial genera in winter and summer $(\mathbf{c})$.

Sphingomonas is a Gram-negative bacterium that belongs to the Alphaproteobacteria class (phylum Proteobacteria). It has a considerable tolerance to various pollutants, toxins, and heavy metals [50]. The abundance of Sphingomonas in each group of CWs substantially increased over time. It had the highest abundance in the CW planted with A. calamus. The content of $\beta-\mathrm{HCH}$ in the rhizosphere substrate of group $\mathrm{C}$ was the lowest. Thus, Sphingomonas was probably the key genus in degrading $\beta-\mathrm{HCH}$. Balázs et al. [38] found that Sphingomonas and Streptomyces had notable responses in soils after receiving lindane 
pollution. Some Sphingomonas isolated from soil were proven to have good degradation ability toward HCH isomers [8]. Xu et al. [51] demonstrated that Sphingomonas can be used as an indicator organism for $\mathrm{HCH}$-contaminated soils to indicate the residue amounts of $\mathrm{HCHs}$, and it can reflect the historical usage of $\mathrm{HCH}$ in contaminated sites, especially $\beta-\mathrm{HCH}$. Moreover, the clustering heatmap at the genus level (Figure S2) was more intuitive in realizing species clustering in the samples. In both seasons, differences at the genus level were more obvious. Furthermore, differences among the groups in the same season were evident at this level. In winter, the abundance of Anaeromyxobacter in the CWs continued to increase as the system operated longer. In summer, Defluviicoccus had the same trend in the CWs. However, no study has reported yet if they have the ability to degrade organochlorine pesticides. Nevertheless, this result was worth noting.

\section{Conclusions}

The average removal rate of $\beta-\mathrm{HCH}$ in the water of each group of $\mathrm{CWs}$ in both seasons was $90.86-98.17 \%$. Furthermore, on average, the removal rate in summer was higher than that in winter, but there was no significant difference $(P>0.05)$. The plants promoted the removal of $\beta-\mathrm{HCH}$ in the CWs. Compared with the CWs without plants, the concentration of $\beta-\mathrm{HCH}$ in water in the CWs with plants decreased significantly in winter $(P<0.01)$ and summer $(P<0.05)$. Among the $C W s$ with plants, the plants could absorb $1.98-3.92 \mu \mathrm{g} / \mathrm{kg}$ $\beta-\mathrm{HCH}$ in winter and $2.5-4.91 \mu \mathrm{g} / \mathrm{kg}$ in summer. $C$. indica had the largest contribution to the uptake of $\beta-\mathrm{HCH}$. The concentration of $\beta-\mathrm{HCH}$ in the substrate of the CWs planted with $A$. calamus was the lowest in both seasons. The presence of plants also decreased the $\beta-\mathrm{HCH}$ content in the CWs' matrix by $5.13 \mu \mathrm{g} / \mathrm{kg}$ than that when no plants were planted. The plants made the bacterial community in the CWs more abundant. With regard to the composition of bacterial community at the phylum level, the CWs in both seasons were relatively similar and mainly contained Proteobacteria, Chloroflexi, Acidobacteria, Rokubacteria, Actinobacteria, and Firmicutes. The difference at the genus level between winter and summer was notable. Numerous species were identified at the genus level. The top 10 bacterial genera accounted for only 13.96-13.98\% of all bacterial genera in both seasons. Actinomycete, Sphingomonas, and Streptomyces had better resistance to $\beta-\mathrm{HCH}$ than the other genera, and their abundance substantially increased as the experiment progressed in summer. On the basis of the phenomenon that the $\beta-\mathrm{HCH}$ in the $\mathrm{CW}$ s was more easily degraded in summer than in winter, Actinomycete, Sphingomonas, and Streptomyces may play a notable role in $\beta-\mathrm{HCH}$ removal.

Supplementary Materials: The following are available online at https://www.mdpi.com/article/10 $.3390 /$ su132313244/s1, Table S1: The final removal rate of $\beta-\mathrm{HCH}$ in water with different constructed wetlands in different seasons, Table S2: The final uptake amount of $\beta-\mathrm{HCH}$ in various plants of constructed wetlands in different seasons, Table S3: The final content of $\beta-\mathrm{HCH}$ in the nonrhizosphere substrate of each constructed wetlands in different seasons, Table S4: The final content of $\beta-\mathrm{HCH}$ in the rhizosphere substrate of each constructed wetland in different seasons, Table S5. The influence of seasons on the bacterial diversity index of constructed wetlands, Table S6: The bacterial community at phylum level varied among different stages of CWs during summer, Figure S1: Rarefaction analyses of multiple samples for winter and summer, Figure S2: Clustering heatmap at the genus level of each CWs for winter and summer, the darker colors indicates the higher abundance of that species in the component. R1 refer to no plant, R2 refer to Acorus calamus, R3 refer to Canna indica, R4 refer to Thalia dealbata, R5 refer to Pontederia cordata.

Author Contributions: Study design and writing-manuscript, Q.C. and Y.L.; writing-review and editing, L.Q.; suggestions on experimental design and data analysis, H.Z. and L.H.; experimental operation and sample analysis, G.P. and X.S. All authors have read and agreed to the published version of the manuscript.

Funding: This research was funded by the National Natural Science Foundation of China (grant number 51868012 and 51578171), the Special Funding for Guangxi 'BaGui Scholar' Construction Projects, and the Natural Science Foundation of Guangxi Province, China (grant number 2018GXNSFAA281186). 
Institutional Review Board Statement: Not applicable.

Informed Consent Statement: Not applicable.

Data Availability Statement: Not applicable.

Conflicts of Interest: The authors declare no conflict of interest.

\section{References}

1. Dong:, J.; Gao, H.; Wang, S.; Yao, H.; Ma, M. Simulation of the transfer and fate of HCHs since the 1950s in Lanzhou, China. Ecotoxicol. Environ. Saf. 2009, 72, 1950-1956. [CrossRef]

2. Tian, C.; Ma, J.; Liu, L.; Jia, H.; Xu, D.; Li, Y.-F. A modeling assessment of association between East Asian summer monsoon and fate/outflow of $\alpha-\mathrm{HCH}$ in Northeast Asia. Atmos. Environ. 2009, 43, 3891-3901. [CrossRef]

3. Wu, Z.; Lin, T.; Hu, L.; Li, Y.; Guo, Z. Semi-centennial sediment records of HCHs and DDTs from the East China marginal seas: Role of lateral transport in catchment. Chemosphere 2021, 263, 128100. [CrossRef]

4. Vijgen, J.; de Borst, B.; Weber, R.; Stobiecki, T.; Forter, M. HCH and lindane contaminated sites: European and global need for a permanent solution for a long-time neglected issue. Environ. Pollut. 2019, 248, 696-705. [CrossRef]

5. Wu, X.; Chen, A.; Yuan, Z.; Kang, H.; Xie, Z. Atmospheric organochlorine pesticides (OCPs) and polychlorinated biphenyls (PCBs) in the Antarctic marginal seas: Distribution, sources and transportation. Chemosphere 2020, 258, 127359. [CrossRef] [PubMed]

6. Srivastava, A.; Shivanandappa, T. Stereospecificity in the cytotoxic action of hexachlorocyclohexane isomers. Chem. Biol. Interact. 2010, 183, 34-39. [CrossRef]

7. Bhatt, P.; Kumar, M.S.; Chakrabarti, T. Fate and Degradation of POP-Hexachlorocyclohexane. Crit. Rev. Environ. Sci. Technol. 2009, 39, 655-695. [CrossRef]

8. Srivastava, V.; Srivastava, T.; Kumar, M.S. Fate of the persistent organic pollutant (POP)Hexachlorocyclohexane (HCH) and remediation challenges. Int. Biodeterior. Biodegrad. 2019, 140, 43-56. [CrossRef]

9. Kumari, K.; Tripathy, J.; Mohapatra, P.; Verma, S.; Das, B.; Raina, V.; Ray, L. Evaluation of toxicity of HCH isomers and its degradation metabolites on mammalian cell line and zebra fish embryos. New Biotechnol. 2018, 44, S151. [CrossRef]

10. Hernandez, R.; Lash, J.P.; Burrows, B.; Wilund, K.R.; Mattix-Kramer, H.J.; Peralta, C.; Durazo-Arvizu, R.A.; Talavera, G.A.; Penedo, F.J.; Khambaty, T.; et al. The association of positive affect and cardiovascular health in Hispanics/Latinos with chronic kidney disease: Results from the Hispanic Community Health Study/Study of Latinos (HCHS/SOL). Prev. Med. Rep. 2019, 15, 100916. [CrossRef] [PubMed]

11. Shah, H.K.; Sharma, T.; Banerjee, B.D. Organochlorine pesticides induce inflammation, ROS production, and DNA damage in human epithelial ovary cells: An in vitro study. Chemosphere 2020, 246, 125691. [CrossRef]

12. Vijgen, J.; Abhilash, P.C.; Li, Y.F.; Lal, R.; Forter, M.; Torres, J.; Singh, N.; Yunus, M.; Tian, C.; Schaffer, A.; et al. Hexachlorocyclohexane $(\mathrm{HCH})$ as new Stockholm Convention POPs-a global perspective on the management of Lindane and its waste isomers. Environ. Sci. Pollut. Res. Int. 2011, 18, 152-162. [CrossRef]

13. Liu, F.F.; Fan, J.; Du, J.; Shi, X.; Zhang, J.; Shen, Y. Intensified nitrogen transformation in intermittently aerated constructed wetlands: Removal pathways and microbial response mechanism. Sci. Total Environ. 2019, 650 Pt 2, 2880-2887. [CrossRef]

14. Cryder, Z.; Wolf, D.; Carlan, C.; Gan, J. Removal of urban-use insecticides in a large-scale constructed wetland. Environ. Pollut. 2020, 268 Pt A, 115586. [CrossRef]

15. Hickey, A.; Arnscheidt, J.; Joyce, E.; O’Toole, J.; Galvin, G.; M, O.C.; Conroy, K.; Killian, D.; Shryane, T.; Hughes, F.; et al. An assessment of the performance of municipal constructed wetlands in Ireland. J. Environ. Manag. 2018, 210, 263-272. [CrossRef]

16. Irwin, N.B.; Irwin, E.G.; Martin, J.F.; Aracena, P. Constructed wetlands for water quality improvements: Benefit transfer analysis from Ohio. J. Environ. Manag. 2018, 206, 1063-1071. [CrossRef] [PubMed]

17. Burgos, V.; Araya, F.; Reyes-Contreras, C.; Vera, I.; Vidal, G. Performance of ornamental plants in mesocosm subsurface constructed wetlands under different organic sewage loading. Ecol. Eng. 2017, 99, 246-255. [CrossRef]

18. Tanner, C.C.; Nguyen, M.L.; Sukias, J.P.S. Nutrient removal by a constructed wetland treating subsurface drainage from grazed dairy pasture. Agric. Ecosyst. Environ. 2005, 105, 145-162. [CrossRef]

19. Park, J.; Cho, K.H.; Lee, E.; Lee, S.; Cho, J. Sorption of pharmaceuticals to soil organic matter in a constructed wetland by electrostatic interaction. Sci. Total Environ. 2018, 635, 1345-1350. [CrossRef] [PubMed]

20. Stottmeister, U.; Wiessner, A.; Kuschk, P.; Kappelmeyer, U.; Kastner, M.; Bederski, O.; Muller, R.A.; Moormann, H. Effects of plants and microorganisms in constructed wetlands for wastewater treatment. Biotechnol. Adv. 2003, 22, 93-117. [CrossRef]

21. Yan, Q.; Xu, Y.; Yu, Y.; Zhu, Z.W.; Feng, G. Effects of pharmaceuticals on microbial communities and activity of soil enzymes in mesocosm-scale constructed wetlands. Chemosphere 2018, 212, 245-253. [CrossRef] [PubMed]

22. Wu, H.; Wang, X.; He, X.; Zhang, S.; Liang, R.; Shen, J. Effects of root exudates on denitrifier gene abundance, community structure and activity in a micro-polluted constructed wetland. Sci. Total Environ. 2017, 598, 697-703. [CrossRef] [PubMed] 
23. Chen, Z.-J.; Tian, Y.-H.; Zhang, Y.; Song, B.-R.; Li, H.-C.; Chen, Z.-H. Effects of root organic exudates on rhizosphere microbes and nutrient removal in the constructed wetlands. Ecol. Eng. 2016, 92, 243-250. [CrossRef]

24. Abdolali, A.; Guo, W.S.; Ngo, H.H.; Chen, S.S.; Nguyen, N.C.; Tung, K.L. Typical lignocellulosic wastes and by-products for biosorption process in water and wastewater treatment: A critical review. Bioresour. Technol. 2014, 160, 57-66. [CrossRef] [PubMed]

25. Tursi, A.; Chidichimo, F.; Bagetta, R.; Beneduci, A. BTX removal from open aqueous systems by modified cellulose fibers and evaluation of competitive evaporation kinetics. Water 2020, 12, 3415. [CrossRef]

26. Wojciechowska, E. Removal of persistent organic pollutants from landfill leachates treated in three constructed wetland systems. Water Sci. Technol. 2013, 68, 1164. [CrossRef]

27. Tursi, A.; Chatzisymeon, E.; Chidichimo, F.; Beneduci, A.; Chidichimo, G. Removal of endocrine disrupting chemicals from water: Adsorption of bisphenol-A by biobased hydrophobic functionalized cellulose. Int. J. Environ. Res. Public Health 2018, 15, 2419. [CrossRef]

28. Tursi, A.; Beneduci, A.; Chidichimo, F.; Vietro, N.D.; Chidichimo, G. Remediation of hydrocarbons polluted water by hydrophobic functionalized cellulose. Chemosphere 2018, 201, 530-539. [CrossRef]

29. Guo, W.; Zhang, H.; Huo, S. Organochlorine pesticides in aquatic hydrophyte tissues and surrounding sediments in Baiyangdian wetland, China. Ecol. Eng. 2014, 67, 150-155. [CrossRef]

30. Tang, X.; Yang, Y.; Tao, R.; Chen, P.; Dai, Y.; Jin, C.; Feng, X. Fate of mixed pesticides in an integrated recirculating constructed wetland (IRCW). Sci. Total Environ. 2016, 571, 935-942. [CrossRef]

31. Dordio, A.V.; Carvalho, A.J. Organic xenobiotics removal in constructed wetlands, with emphasis on the importance of the support matrix. J. Hazard. Mater. 2013, 252-253, 272-292. [CrossRef]

32. Zhang, D.Q.; Gersberg, R.M.; Zhu, J.; Hua, T.; Jinadasa, K.B.; Tan, S.K. Batch versus continuous feeding strategies for pharmaceutical removal by subsurface flow constructed wetland. Environ. Pollut. 2012, 167, 124-131. [CrossRef]

33. Torralba-Sanchez, T.L.; Kuo, D.T.F.; Allen, H.E.; Di Toro, D.M. Bioconcentration factors and plant-water partition coefficients of munitions compounds in barley. Chemosphere 2017, 189, 538-546. [CrossRef]

34. Vymazal, J.; Brezinova, T. The use of constructed wetlands for removal of pesticides from agricultural runoff and drainage: A review. Environ. Int. 2015, 75, 11-20. [CrossRef]

35. Romeh, A.A. Phytoremediation of water and soil contaminated with imidacloprid pesticide by Plantago Major, L. Int. J. Phytoremediat. 2010, 12, 188-199. [CrossRef] [PubMed]

36. Meng, P.; Pei, H.; Hu, W.; Shao, Y.; Li, Z. How to increase microbial degradation in constructed wetlands: Influencing factors and improvement measures. Bioresour. Technol. 2014, 157, 316-326. [CrossRef]

37. Truu, M.; Juhanson, J.; Truu, J. Microbial biomass, activity and community composition in constructed wetlands. Sci. Total Environ. 2009, 407, 3958-3971. [CrossRef]

38. Balázs, H.E.; Schmid, C.A.O.; Podar, D.; Hufnagel, G.; Radl, V.; Schröder, P. Development of microbial communities in organochlorine pesticide contaminated soil: A post-reclamation perspective. Appl. Soil Ecol. 2020, 150, 103467. [CrossRef]

39. Al-Ani, M.A.M.; Hmoshi, R.M.; Kanaan, I.A.; Thanoon, A.A. Effect of pesticides on soil microorganisms. J. Phys. Conf. Ser. 2019, 1294, 072007. [CrossRef]

40. Wołejko, E.; Jabłońska-Trypuć, A.; Wydro, U.; Butarewicz, A.; Łozowicka, B. Soil biological activity as an indicator of soil pollution with pesticides-A review. Appl. Soil Ecol. 2020, 147, 103356. [CrossRef]

41. Rangasamy, K.; Athiappan, M.; Devarajan, N.; Samykannu, G.; Parray, J.A.; Aruljothi, K.N.; Shameem, N.; Alqarawi, A.A.; Hashem, A.; Abd Allah, E.F. Pesticide degrading natural multidrug resistance bacterial flora. Microb. Pathog. 2018, 114, 304-310. [CrossRef] [PubMed]

42. Behera, P.; Mohapatra, M.; Adhya, T.K.; Suar, M.; Pattnaik, A.K.; Rastogi, G. Structural and metabolic diversity of rhizosphere microbial communities of Phragmites karka in a tropical coastal lagoon. Appl. Soil Ecol. 2018, 125, 202-212. [CrossRef]

43. Ansola, G.; Arroyo, P.; Saenz de Miera, L.E. Characterisation of the soil bacterial community structure and composition of natural and constructed wetlands. Sci. Total Environ. 2014, 473-474, 63-71. [CrossRef]

44. Regar, R.K.; Gaur, V.K.; Bajaj, A.; Tambat, S.; Manickam, N. Comparative microbiome analysis of two different long-term pesticide contaminated soils revealed the anthropogenic influence on functional potential of microbial communities. Sci. Total Environ. 2019, 681, 413-423. [CrossRef]

45. Benimeli, C.S.; Amoroso, M.J.; Chaile, A.P.; Castro, G.R. Isolation of four aquatic streptomycetes strains capable of growth on organochlorine pesticides. Bioresour. Technol. 2003, 89, 133-138. [CrossRef]

46. Fuentes, M.S.; Benimeli, C.S.; Cuozzo, S.A.; Amoroso, M.J. Isolation of pesticide-degrading actinomycetes from a contaminated site: Bacterial growth, removal and dechlorination of organochlorine pesticides. Int. Biodeterior. Biodegrad. 2010, 64, 434-441. [CrossRef]

47. Sineli, P.E.; Tortella, G.; Dávila Costa, J.S.; Benimeli, C.S.; Cuozzo, S.A. Evidence of $\alpha$-, $\beta$ - and $\gamma$-HCH mixture aerobic degradation by the native actinobacteria Streptomyces sp. M7. World J. Microbiol. Biotechnol. 2016, 32, 81. [CrossRef] [PubMed] 
48. Zhang, H.; Xu, L.; Huang, T.; Yan, M.; Liu, K.; Miao, Y.; He, H.; Li, S.; Sekar, R. Combined effects of seasonality and stagnation on tap water quality: Changes in chemical parameters, metabolic activity and co-existence in bacterial community. J. Hazard. Mater. 2021, 403, 124018. [CrossRef] [PubMed]

49. Long, Y.; Yi, H.; Chen, S.; Zhang, Z.; Cui, K.; Bing, Y.; Zhuo, Q.; Li, B.; Xie, S.; Guo, Q. Influences of plant type on bacterial and archaeal communities in constructed wetland treating polluted river water. Environ. Sci. Pollut. Res. Int. 2016, 23, 19570-19579. [CrossRef]

50. Sharma, M.; Khurana, H.; Singh, D.N.; Negi, R.K. The genus Sphingopyxis: Systematics, ecology, and bioremediation potential-A review. J. Environ. Manag. 2021, 280, 111744. [CrossRef]

51. Xu, Y.; Niu, L.; Qiu, J.; Zhou, Y.; Lu, H.; Liu, W. Stereoselective accumulations of hexachlorocyclohexanes (HCHs) are correlated with Sphingomonas spp. in agricultural soils across China. Environ. Pollut. 2018, 240, 27-33. [CrossRef] [PubMed] 